\title{
DEVELOPMENT OF COACHING TECHNOLOGIES IN THE EDUCATIONAL SPACE OF THE UNIVERSITY
}

\author{
Makhzuna Shavkatovna Ismatova
}

Phd Student, Samarqand State Institute Of Foreign Languages, Samarkand, Uzbekistan

\section{ABSTRACT}

This paper highlights modern innovative approaches to the organization of the educational process in higher educational institutions based on coaching technologies. The specificity of the integration of coaching technologies in the educational process of higher education is stated. The essence and features of coaching and related concepts of training, consulting and mentoring are considered.

KEYWORDS:- coaching, training, consulting, mentoring, modern coach technology in the educational process, coaching technologies, educational process, higher education.

\section{INTRODUCTION}

The higher education system is an undeniable and powerful factor in overall progress. In transitional eras, which are characterized by deep systemic changes, the role of higher education is especially actualized, because it is it that determines the quality of the intellectual potential that is capable of generating new ideas for laying out reform routes and creating "human material" capable of making a breakthrough into a new civilized dimension. It is higher education that becomes the "point" of growth of the "new knowledge economy", the modernization of socio-political and socio-economic spheres. Science and education are the basis for the formation of human capital. The scientific segment provides idea generation, research and development of innovations. The educational segment makes it possible to ensure the diffusion of innovations and their industrial use.

In theory, it is the educational segment that underlies the innovative activity of higher education. On the one hand, it ensures the availability of specialists who can develop innovations, on the other hand, the educational segment ensures the availability of specialists who can use the innovations created in the scientific segment. In addition, this segment provides the economy with specialists who are able to introduce innovations into practical use. This, in turn, actualizes the issue of the mission of higher education in the historical transformation process, through the implementation of a full-fledged modernization of education. [4]

Recently, the statement about the crisis of higher education has become almost universal. One of 
CURRENT RESEARCH JOURNAL OF PEDAGOGICS 2(5): 134-141, May

2021 DOI: https://doi.org/10.37547/pedagogics-crjp-02-05-25

ISSN 2767-3278

(C)2021 Master Journals

\section{Crossref do) 81 Google}

Accepted 25th May, 2021 \& Published 31 ${ }^{\text {th }}$ May, 2021

the main problems was that a sharp increase in the number of students in certain areas inevitably led to a drop in the quality of training. Changing the preferences of young people themselves is currently a serious problem. The state itself had a significant impact on such deformations of consciousness. The conniving policy towards higher education distorted the previously existing system of higher education and created a new "skewed" system, in which there was no room for creativity, honesty, worries about the fate of the country. The work of highly qualified specialists is now valued less, teenagers see their careers more in the form of devotional service than the development of their own abilities and demonstration of intelligence, which is a very dangerous tendency. The most important task of the modern educational process in higher education is the production of highly qualified personnel who are able to optimally solve practical production and management issues.

The problem of the qualitative development of the higher education sector is aggravated by the fact that, due to low wages, most teachers work in several universities simultaneously. Naturally, this practically disappears the opportunity to devote time to advanced training, self-education, improving the courses taught, developing business games, writing textbooks, studying with graduate students and students, which also does not contribute to an increase in the level of teaching. The result is the destruction of previously existing scientific schools, a general decline in the quality of higher education, which was previously considered one of the highest in the world. [6]

In these conditions, there is a need to reform and modernize educational processes, which will require higher professional qualities of teachers, greater ability to work in conditions of strict priorities and restrictions, more complete mutual understanding of managers and researchers. It is necessary to take a fresh look at the role of the teacher and at the educational a process, which in turn requires a revision of the teacher's competencies. Increasing requirements for the efficiency and effectiveness of the learning process necessitated the use of innovative technologies in pedagogy.

The development of pedagogical innovation in our country is associated with the mass social and pedagogical movement. Today, every step of a teacher, any of his initiatives are associated with the need to introduce new pedagogical ideas, consistent development of innovative educational technologies. The modern innovative approach involves the awareness and use of qualitatively new personal categories, which should become not just desirable qualities of a teacher, but real key professional competencies.

One of the innovative directions in the field of higher education is coaching - a new discipline that has its own subject, objectives, philosophy, principles, directions and basic procedure. Many of the foundational principles of coaching can be successfully applied in pedagogy. They allow you to create a new approach to the learning process, introduce interactive elements, new meaning for both teachers and students, create involvement in the process, increase motivation and responsibility for the result.

Coaching has its roots in the field of sports and is based on the methodology of positive, cognitive and organizational psychology. Currently, this doctrine continues to develop at the intersection of psychology, management, philosophy, logic and life experience. In this regard, the essence of coaching should be determined based on the current level of its development.

Coach is an English word that is translated in most dictionaries as a) stagecoach, carriage delivering to destination (old), b) coach in professional sports (head coach), whose task is not so much to teach the ward to "hold the stick" 
CURRENT RESEARCH JOURNAL OF PEDAGOGICS 2(5): 134-141, May

2021 DOI: https://doi.org/10.37547/pedagogics-crjp-02-05-25

ISSN 2767-3278

(C)2021 Master Journals

Crossref doi 8 Google

Accepted 25th May, 2021 \& Published 31 th May, 2021

how much to teach how to win and achieve maximum results, accompany the athlete in achieving maximum sports results. Coach and trainer are often used synonymously. However, there is a significant difference between them, since a coach is a person who professionally teaches in order to form certain skills in the ward.

An excursion into the etymology of the word "coach" allows us to assert that it appeared in the 16th century and is of Hungarian origin. Initially, this was the name of a "good carriage", a carriage, a carriage. Now coach is translated not only as a coach, but also as "good bus" - a bus for international flights (as opposed to bus - a simple bus).

In the 19th century, the word "coach" was first entrenched in sports (coach), and later became widely used by the British already to denote any activity related to teaching, mentoring, instructing and consulting. In England, "coach" was the name given to private tutors who help students learn a university course. The professional duties of the tutors were to prepare the student for exams or, more precisely, to understand where the student is weak, what areas he knows, to help the student to tighten up knowledge gaps, to motivate him to work independently and to help overcome internal and external obstacles in preparing for the exam and passing the exam. In this regard, the criteria for the quality assessment of the coach were quite simple - whether the student passed the exam or not. Originating in the 80s of the XX century as a practical answer to the need of modern business for effective management, coaching became widespread and gained popularity first in America, and then in Europe and Asia, very soon it took shape as an independent science, an interdisciplinary scientific discipline. Key figures in this process were John Whitmore, Tim Gallvey, and Thomas J. Leonard.
The pioneer of the development of the sports direction in business was a graduate of Harvard University, captain of the university tennis team Tim Gallvey. He was the first to transfer sports methods to management and business. [1]. In the 80 s, the sports direction, thanks to the efforts of Thomas Leonardo and J. Whitmore, the author of the famous book "Coaching for perfomance" 1992 (GROW OW coaching technology) developed in the form of coaching, which came to Russia at the beginning of the 21st century [5].

While working as a financial consultant, the founder of coaching, Thomas J. Leonard, noticed that his most successful clients need not only consulting, but also personal support of professional activity, formalizing this type of activity, introduced the concept of "coach", borrowing it from sports (eng. coach - tutor, instructor, coach), and has achieved outstanding results by creating the coaching industry. In 1994, he founded the International Coaching Federation (ICF), which formulated the main attributes of coaching as an independent scientific discipline. As a science, coaching dissociated itself from consulting and psychotherapy. If Thomas J. Leonard came to coaching from financial consulting, then John Whitmore brought sports coaching to management and corporate business, becoming the founder of the corporate coaching business line.

Today, coaching should be seen not only as a science, but also as an art, which is based on sports ideology and widely uses the principles, analogies and methods used in sports. In modern conditions, when both sport and management have reached a sufficiently high level of development, their "strong analogy" is actualized and acquires cognitive, methodological and practical significance.

Today the word coaching is rapidly entering the modern business lexicon of Russian business and 
CURRENT RESEARCH JOURNAL OF PEDAGOGICS 2(5): 134-141, May

2021 DOI: https://doi.org/10.37547/pedagogics-crjp-02-05-25

ISSN 2767-3278

(C)2021 Master Journals

Crossref doi 8 Google

Accepted 25th May, 2021 \& Published 31 th May, 2021

occupies a worthy place along with such concepts as consulting, management, marketing, branding and others. Despite the fact that this term is interpreted by various specialists in a very differentiated way, it is fundamental that coaching is a tool that creates an effective direction for professional and personal development. Thus, taking its origins in the sports environment, having passed the field of business, today coaching has been introduced into the educational sphere. On the basis of the introduction of coaching technologies, the innovation of the educational process is carried out, which makes it possible to train highly qualified specialists adapted to the changing conditions of the external environment, at the same time, the growth of qualifications and professionalism of the university staff will be ensured, as well as an increase in the creative and vital activity of both the teaching staff and students enrolled in university.

In higher education pedagogy, coaching can constructively solve numerous psychological and pedagogical problems. It allows you to solve one of the most pressing problems of the educational process - to manage the student's motivation, offering the teacher a technology that gives a guaranteed result and the ability to direct a future high-class world-class specialist to work in a creative environment. As a rule, modern teaching in universities is based on the transfer by teachers of their rich professional experience on the principle of "do as I do". However, when using the coaching methodology in the learning process, the role of the teacher is significantly enriched. A teacher who is proficient in coaching technologies can help the student to determine the direction of scientific research and at the same time effectively use his inner potential.

In the course of conducting research, coaching helps to activate the systemic vision of the researcher, and also provides a creative approach to solving tasks and emerging difficulties or problems. Professional experience combined with coaching allows us to educate a true master of his craft, capable of creatively solving modern problems. As a result, we can say that coaching as training helps in the development of cognitive skills and abilities, the formation of new thinking strategies. At the same time, the emphasis is on the new material, and not on past results. The main driving force behind coaching technologies is that in the course of using the appropriate methods, the coach-teacher seeks not only to instill in the student self-confidence, but also to transfer to him the technology of self-coaching.

The innovation process alternates search and selection, research and synthesis, cycles of generation (divergence) and analysis (convergence) of ideas. The creation of such an intellectual enzyme as divergence, or "creative synthesis" (the fusion of previously considered incompatible skills or ways of thinking), is extremely important for the innovative learning process. Of course, the more radical creative ideas are received, the greater the likelihood of finding a fundamentally new solution to the problem. By looking at the same problem with different eyes and listening to the thoughts of colleagues, listeners are inspired to look for new solutions beyond the obvious. The idea management process can be carried out using the relaxed-strict leadership method, by creating an innovative vision that inspires the audience. Thus, coaching provides an opportunity for both teachers and students to change their outlook on the world around them, on existing situations. The technologies underlying coaching stimulate the rapid growth of creativity and bring to a new level of communication and the quality of interaction of participants in the educational process.

Organized and well-managed creative activities lead to the successful generation of creative ideas. When a sufficient number of innovative 
CURRENT RESEARCH JOURNAL OF PEDAGOGICS 2(5): 134-141, May

2021 DOI: https://doi.org/10.37547/pedagogics-crjp-02-05-25

ISSN 2767-3278

(C)2021 Master Journals

\section{Crossref do) 81 Google}

Accepted 25 $5^{\text {th }}$ May, 2021 \& Published 31 $1^{\text {th }}$ May, 2021

ideas have been generated, you can move on to the next phase - choosing the best solution using the convergence process - evaluating and ranking the ideas put forward. [2]

Of course, many teachers have long been using the coach approach when teaching their students, which is very effective both for the students and for the teachers themselves. For students, the effectiveness of this method is expressed in the fact that each of the students understands that the teacher is working with him, and works to achieve precisely his result, and not the group as a whole. On the part of the teacher, the effectiveness of working with a coach approach lies in the fact that he receives feedback, analyzing specific results, and when working with the next group, his training becomes more effective.

The practice of foreign researchers shows that the effectiveness of coaching is superior to traditional teaching methods. Learning becomes not only a function of transferring knowledge to students and teaching their skills, but also realizes the function of stimulating interest in learning, moving towards awareness, developing strengths, unleashing a person's potential and making the teaching process more interesting and effective. In this regard, when presenting educational material, the "coaching" approach becomes one of the most important components of effective and high-quality education.

How is the coach approach built in the classroom? First of all, it is a clarification of the goals and objectives. The orientation of the upcoming material, its tasks and ways of using this material by listeners in practice are determined. For example, what will be discussed in the upcoming lesson, and how the proposed material can be used by the listener in a particular case. The coach's task is to help each listener, with the help of leading questions, to define himself and get feedback. In this regard, we can say that coaching is the ability to ask strong questions not in order to gather information, but in order to invite a person to listen to himself, to help him create ideas and get his solutions. Strong questions invite introspection, provide complementary solutions, and lead to creativity and insight. Strong questions invite the person to look inward or into the future Strong questions lift constraints and give room for ideas. The methodology of strong open-ended questions of coaching, used in the educational process, will allow to expand the framework of consciousness, stimulate the search for answers and solutions, build logical and cause-and-effect relationships, and promote in-depth analysis.

The second step will be to identify ways to achieve this goal. What steps must be taken to achieve it. Next, you should determine the reason why the listener still needs to deal with the proposed topic. Naturally, the first two stages are very important, but understanding the importance and feasibility of these steps is also important. It is important for the listener to understand the need for a particular step. If understanding appears, interest is shown or not. And here it is worth moving on to the next stage. Clarification of the individual listener's own values, not generally accepted, but his own. Based on this, the student understands what exactly he needs to get from studying at the university, and how this is consistent with his personal and professional goals. In addition, the trainees have additional motivation to learn.

And the very last stage is the realization that the goal has been achieved, that what is planned has worked out and expectations are fully aligned with the result.

In addition to the fact that coaching is able to enable teachers to individually support a student, which determines his professional, personal growth and an increase in personal 
efficiency, it also ensures greater productivity of the activity and the study group as a whole. The undoubted results of coaching, as shown by practical research, are the improvement of relationships in the group, the ability to respond quickly and effectively in educational and practical situations, flexibility and adaptability to changes in the educational process and the environment.

Considering the possibilities of using coaching technologies in the educational process, one

\section{Table}

Differences between Coaching, Training, Consulting and Mentoring

\begin{tabular}{|c|c|c|c|}
\hline METHOD & TARGET & USING & LIMITATION \\
\hline Training & $\begin{array}{lcr}\text { Acquiring } & \text { specific } & \text { skills, } \\
\text { changing } & \text { attitudes } & \text { towards } \\
\text { work } & & \end{array}$ & $\begin{array}{l}\text { Lack of knowledge and } \\
\text { skills to do the job } \\
\text { effectively }\end{array}$ & $\begin{array}{l}\text { When "transferring" skills } \\
\text { from the classroom to } \\
\text { reality, an individualized } \\
\text { approach is not always used. }\end{array}$ \\
\hline Consulting & $\begin{array}{l}\text { "Buying" a solution to a } \\
\text { problem in a certain "expert } \\
\text { area" that cannot be effectively } \\
\text { solved within the organization } \\
\text { (there is no time, knowledge, } \\
\text { and it is more profitable to buy } \\
\text { a solution "on the side") }\end{array}$ & $\begin{array}{l}\text { Costs must be carefully } \\
\text { calculated. }\end{array}$ & $\begin{array}{l}\text { Increased competence of } \\
\text { employees in terms of how } \\
\text { to solve the problem is } \\
\text { limited. }\end{array}$ \\
\hline Mentoring & $\begin{array}{l}\text { Exchange of experience within } \\
\text { the organization, when there } \\
\text { are employees who are } \\
\text { competent in resolving issues. }\end{array}$ & $\begin{array}{l}\text { Transfer of lessons learned } \\
\text { from more experienced } \\
\text { employees to less } \\
\text { experienced employees } \\
\text { within the organization }\end{array}$ & $\begin{array}{l}\text { The transfer of "off the } \\
\text { shelf" solutions rarely } \\
\text { fosters new initiatives }\end{array}$ \\
\hline Coaching & $\begin{array}{l}\text { Development of independence } \\
\text { and responsibility for the result } \\
\text { of the employee }\end{array}$ & $\begin{array}{l}\text { Ability to innovate and } \\
\text { personal responsibility for } \\
\text { the result. }\end{array}$ & $\begin{array}{l}\text { Requires special skills and } \\
\text { encouragement of } \\
\text { employees' independence } \\
\text { and responsibility. }\end{array}$ \\
\hline
\end{tabular}

The main problem of the training program is that the participant who has returned from the cannot fail to mention such related concepts as training, consulting and mentoring, which are very actively used in the format of coaching teaching. For example, coaching, as a process of transferring a new skill to real life, can be considered a real continuation of training, which is focused on the formation of skills. However, there are still differences between coaching and consulting, training and mentoring, a brief description of which is presented in the table. 
CURRENT RESEARCH JOURNAL OF PEDAGOGICS 2(5): 134-141, May

2021 DOI: https://doi.org/10.37547/pedagogics-crjp-02-05-25

ISSN 2767-3278

(C)2021 Master Journals

Crossref do: 81 Google

Accepted 25th May, 2021 \& Published 31 th May, 2021

training to the "harsh everyday life" of everyday business. The main limitation of trainings as a method of improving performance is that it is impossible to create and "work out" ready-made solutions suitable for all situations without exception, skill development does not provide universal solutions, but gives, first of all, a limited set of behavior patterns. This limitation is especially clearly manifested in the context of a narrow "technological" approach to personnel management or interaction with people.

Skills training is used to:

- replenishment of missing knowledge;

- correction of shortcomings in the performance of the employee's job duties;

- bringing to automatism the skills of working in crisis situations;

- consolidation of work skills in the performance of functions that are especially important for the company (customer service, product quality).

The modern understanding of mentoring is really very close to coaching. In either case, both the client and the protégé themselves are engaged in the formulation of their goals, explore reality, make a decision and follow the chosen path. Coaching and mentoring can also be part of the same project or process. However, unlike coaching, mentoring appears as general guidance or advice about a life issue or career. Mentors rely on the advancement of pre-existing knowledge or professional skills. Coaching, which covers a wide range of issues, is a much more general process than coaching, which is specific to a specific skill or area of activity. Mentoring usually promotes progress within a specific area or organization and helps individuals evaluate corporate policy (in its network, profile and organizational aspects). More often than not, the mentor takes a higher position than the person he leads. A mentor is both a role model that can become a guide for the follower on a personal level, and, undoubtedly, an authority in a certain area. The listener does not need to puzzle over how to transfer knowledge from theory to practice. In this regard, mentoring is broader than coaching. Coaching is more often focused on a specific skill, a specific field of activity.

Consulting in most cases focuses on emotions and feelings, and not on the achievement of performance. Consulting is focused on finding the source of problems in the past, coaching is focused on achieving results in the future. A consultant is usually a specialist in a specific area of business or knowledge. A consultant is usually approached by people who need help in solving complex and specific problems. In the course of counseling, the reasons for the problems that have arisen are clarified and the past personal experience is considered in the context of events that have come to the present state of affairs, as a result of which an expert position is given on this issue. Unlike traditional consulting, coaching shifts the focus to the future. His task is to develop a route of movement to a predetermined goal, a result. The methodology and tools of coaching are based on interactive communication, discussion: question-answer (Q\&A), which is carried out in the form of coaching sessions. This can be a personal meeting, telephone contact, communication on the Internet.

Coaching in the educational process of higher education is a new direction of activity that enriches the educational process and increases its effectiveness. This is an additional offer of the business school, providing an expansion of the educational package. This is a powerful additional tool for the development of new skills that stimulates the motivation and responsibility of trainees for the result. The end result of educational activity should be the readiness of graduates to successfully advance in a personal, 
CURRENT RESEARCH JOURNAL OF PEDAGOGICS 2(5): 134-141, May

2021 DOI: https://doi.org/10.37547/pedagogics-crjp-02-05-25

ISSN 2767-3278

(C)2021 Master Journals

\section{Crossref do) 81 Google}

Accepted 25 $5^{\text {th }}$ May, 2021 \& Published 31 ${ }^{\text {th }}$ May, 2021

professional and social environment. In this regard, the introduction of coaching trainings during the period of preparation of a diploma will enable students to more consciously and responsibly approach their thesis defense, will allow them to determine the direction in future work and allow them to build effective steps to achieve their goals, and most importantly, to successfully find a job.

Coaching technology can be successfully applied in the teaching process of various disciplines, and also opens up many prospects for improving the learning process. As a learning style, coaching can be used in any form of the educational process: when conducting seminars, colloquia, performing research, coursework and diploma theses. A new area of activity should be special additional training of a teacher, change and adaptation of curricula for coaching technologies, which will increase the involvement of students in the process of identifying their real needs. The introduction of coaching into a series of advanced training programs for university teachers will help improve the effectiveness of educational activities in universities. Today it is one of the most important areas, along with the use of new information and communication technologies in education. Of course, each university must independently determine for itself those coaching methods that will be most fruitful for educational activities, the forms of bringing this knowledge to its employees and the criteria for assessing the effectiveness of the implementation of coach technologies in the educational process.

Coaching can be used not only as a teaching style, but also as a way of interacting with colleagues, pupils, students. This approach allows you to take a fresh look at the essence of the process itself and opens up new opportunities for the development of the emotional intelligence of teachers. Effective coaching leads the teacher to achieve the goal, brings satisfaction and joy, from which all participants in the educational process benefit.

\section{ReFERENCES}

1. W. Timothy Gallwey. The Inner Game of Work: Focus, Learning, Pleasure, and Mobility in the Workplace. -M :: "Alpina Business Books", 2005. - 252 p.

2. Котельников В.Ю. Ten3: Управление инновациями: стратегический подход. Гибкие корпоративные стратегии выживания и лидерства в новой экономике. - М.: Эксмо, 2007. - 96 с. (Бизнес-коуч).

3. Смирнов В.Н. «Спортинг - менеджмент побед! Теория и практика современного менеджмента: от тейлоризма до спортинга». - СПб.: Эрида-Бизнес, 2011. $-240 \mathrm{c}$.

4. Трушевская А.А.. Развитие высшей школы: региональный потенциал модернизации. Университет в регионе: наука, образование, культура: материалы науч.-практ.конф 5-6 декабря 2006 / Отв.ред. Е.М. Кокорев, Л.П. Бирюкова Магадан: Изд. СМУ, 2007. - С. 46-49.

5. Whitmore J. Coaching - a new style of management and personnel management: A Practical Guide. - M .: Finance and Statistics, 2001.

6. Хайруллин Н.Г. Проблемы и перспективы развития высшей школы: региональный потенциал модернизации // Проблемы современной экономики. - 2005. №3/4. - С. 358. 